\title{
Kannur: Inside India's Bloodiest Revenge Politics
}

\section{Ullekh N.P, Haryana: Penguin Random House India, 2018, xviii., 223 pp. Rs.499}

\section{ISBN: 9780670090693}

\section{Vishnu Achutha Menon ${ }^{\dagger}$}

Kannur is a beautiful coastal district of Kerala, which made its way to the national headlines for its brutal political murders. The state has the highest social development parameters when compared to other states but despite this, what makes Kannur standout in terms of political happenings is a matter to be discussed. Ullekh N.P., a native of Kannur who is the son of the late Marxist leader Pattiam Gopalan, analyses the reasons and motivations behind these political vendettas. The book has nine chapters running to 223 pages with a foreword written by Sumantra Bose from the London School of Economics and Political Science.

Chapter one describes the waves of violence that spread throughout the state in the form of murders of prominent political leaders like Azhikodan Raghavan, Moyarath Sankaran, P.C Anathan, Punnakkodan Kunhambu, V Narayan Nambiar, O.P Ananthan, and K.G Marar, who were killed for cheap political gains. From 1972 to December 2017, 200 people died in Kannur's political violence, 78 were from $\mathrm{CPI}(\mathrm{M}), 68$ from the RSS-BJP, 36 from Congress, eight from Indian Union Muslim League, two each from Communist Party of India (CPI) and Popular Front of India (PFI) (p.12). The book also sheds light on the dominant role played by the political parties in the day to day affairs of the people. In northern Malabar matrimonial choices were preferred from families belonging to the same party. Thus, party affiliations become inseparable from the family choices. In 1967, Congress party faced defeat in the general elections after the death of Jawaharlal Nehru.
The same year also marked the emergence of a new opponent in Kannur, the RSS. The government, led by EMS Namboodiripad, brought pro-labour reforms in the beedi (a similar form but cheaper than cigarettes composed of unprocessed tobacco wrapped in leaves) sector. The federal act was passed, which included several provisions to ensure the welfare of the beedi workers. These reforms were implemented in September 1968. During the time, RSS maintained strong financial links with Mangalore Ganesh Beedicompany, and hence, they decided to shut shops in Kerala on 15 October 1968 resulting in 12,000 workers losing their jobs. This led to the launch of Dinesh Beedi. ${ }^{1}$

The second chapter, titled "First Blood" deals with the allegations against the current Chief Minister, Pinarayi Vijayan's role in a murder case. Vadikkal Ramakrishnan died on 28 April 1969 at Thalassery hospital. He was killed in a counter-attack on the RSS by the CPI(M) in response to a fight against the Communist leader, Kodiyeri Balakrishnan, the serving State Secretary of CPI(M). The CPI(M) led government of EMS Namboodiripad had manipulated witnesses to save Vijayan. In 2016, PinarayiVijayan assumed his office as twelfth Chief Minister of Kerala. According to RSS, Vijayan is the most hated leader of Kerala, who has unleashed the relentless countrywide

\footnotetext{
${ }^{+}$Department of Media and Communication, Central University of Tamil Nadu, Thiruvarur - 610005, Email:vishnuamenon@gmail.com

${ }^{1}$ Dinesh Beedi is the first Cooperative Society set up by the workers in Kerala. It consists of more than 12000 workers.
} 
propaganda, called Redrocity. ${ }^{2}$ In a Public Relations makeover, Pinarayi Vijayan became the symbol of CPI(M)'s muscular politics.

Chapter three, Vignettes of Grief and Rage deals with personal memoirs of Ullekh's reflections while visiting the victim's family. He mentions in the book that violence between RSS and CPI(M) workers used to be somewhat unusual in Kannur. All parties in the region apply the concept of " numberittukollal" (murder to equal tally). Ullekh has narrated some incidents revealing this commonly used strategy. In May 2016, two CPI(M) men were killed, PV Raveendran and CV Dhanaraj. In the following months, several party members, Ramachandran, Mavila Vineesh, Jijesh and Ezhuthan Santosh from CPI(M) and RSS were killed. Following these incidents, on 12 October 2016, the then BJP President, Amit Shah tweeted that attacks on BJP workers are a political vendetta.

Chapter four entitled The Spell of the Northern Ballads links Northern Ballads to the modernday political clashes and the ancient Chekavar ${ }^{3}$ tradition. Chekavars were trained in Kalaripayattu (Martial art) and readied for wars meant for upholding the honour of their princelings or wealthy local kings. If two princes announced a spar, their hired Chekavars would face each other until one of them died in the duels. It is also said in the book that Kannur's rich legacy of temple art (Teyyam), belligerent deities (Ugramurtis), and Teyyamidols have their origins in the ordinary people, who were martyrs in the fight against feudalism. The temples or Teyyakavuswere the first memorials dedicated to the martyrs (Sasidharan, 2012).

Chapter five ,The Flag-Bearers talks about the militant peasant and labour movements which have contributed immensely in shaping the Kannur's political culture. The best-known myth about Kerala's origin is related to Parasurama who created the state and gave the Nambudiris control over the land. Nayars were expected to revere their Nambudiri superiors. These communities followed matrilineal (the centrality

\footnotetext{
${ }^{2}$ Redrocity (Red-Atrocity) is referred to notorious political killings carried out by communist party against BJP - RSS workers.
}

of women as the focus of lineage, family and inheritance) inheritance of power. Thiyya (in northern Kerala) or Ezhava (in central and southern Kerala) families cultivated the coconut palm and worked on the land. Pulayas or Parayas did the work of paddy cultivation and were treated as slaves. Muslims shared a similar status of the Nayars. Communist moments began when caste and class discrimination in India was extreme; the lower caste faced daily humiliation, violence rape and abuse. Kannur had seen an intense concentration of land among upper castes, that is, Namboodiris and Nairs. The majority of the poor lower castes were landless. In 1934, a pro-socialist faction of Congress Party at the national level, Congress Socialist Party (CSP) was formed. CSP was destined to lead the farmer struggles. The early leaders of CSP were Acharya Narendradev, Jayaprakash Narayan, MinooMasani, Abdul Bari, Purushottam Trikamdas, Sampuranand, Ram Manohar Lohila, NG Ranga, E.M.S Namboodiripad and AchyutPatwardhan. Besides EMS, CSP leaders from Kerala included P.Krishna Pillai and A.K Gopalan. Krishna Pillai found Kannur a fertile ground for launching peasant struggles. Between 1934 and 1939, nearly 80 local trade unions were organised industry-wise in almost all the urban centres of Kerala. In 1939, the first Kerala unit of the Communist Party of India was established secretly at Parappuram, near Pinarayi. Krishna Pillai became the first secretary of CPI Kerala faction.

Chapter six, Congress versus the Communists, deals with the political rivalries between Congress and Communists. According to the district crime records, nineteen $\mathrm{CPI}(\mathrm{M})$ activists, six congress workers and one IUML worker were killed in the 1980s. From 1990-99, fourteen $\mathrm{CPI}(\mathrm{M})$ cadres and sixteen Congressmen were killed. The remaining part of the chapter talks about the rise of leaders like A.K Gopalan, M.V Ragahavan, E.K. Nayanar and K. Sudhakaran.

Chapter seven is titled The Religion Card which deals with the role played by religion in

${ }^{3}$ Chekavars belong to Thiyya (OBC) caste who were warriors of the community. 
determining the political climate of Kannur. Kerala consisted of three regions: the two princely states, namely Kochi and Travancore; and the British-ruled Malabar. The state is home to over 54 per cent Hindus; the rests are Muslims and Christians. In the 1940s, communism made entry to Kannur attracting mainly people from communities such as Ezhavas/Thiyyas and the Scheduled Castes. The RSS mostly included people belonging to Brahmins and Nambiar/Nair castes. The BJP government came to power at the Centre in 2014, but in Kerala, BJP-RSS failed to attract the vote bank due to the overwhelming presence of Marxists who took up a vow to uphold pluralism. CPI(M) always managed to secure the votes of Hindus; CPI(M) won the goodwill of the people belonging to the $\mathrm{OBC}$ community due to successful redistribution of land by the communist governments in the past. Until the 1990s, a majority of its leaders were from the upper-caste Hindus and cadres were from the OBCs. Left had distanced itself from Muslim parties, sticking to Hindu voters as its mainstay. The Islamist Popular Front of India locks horns more with the $\mathrm{CPI}(\mathrm{M})$ than with the RSS. However, recent data appearing in national dailies suggest that many pro-ISIS groups are budding in the Malabar region. In the past, RSS had only twenty-one shakhas(the basic units of the organisation) in the Malabar area. While in a recent report, RSS has 4500 units throughout Kerala which records highest in the country(Express, 2020). Religion acts as the major trump card for all the political parties in Kerala. In 2015, Bharath Dharma Jana Sena(BDJS) political wing of Sree Narayana Dharma ParipalanaYogam (SNDP) was formed. They had an official alliance with the National Democratic Alliance (NDA). The main intention of this coalition was to snatch away OBC votes from the CPI(M). As a result of this, in 2019, NDA improves its vote share from $11.7 \%$ to 28.68\%(Kallungal, 2019).

Chapter eight, The Anatomy of a Conflict is about the genesis of the violence in Kannur. Ullekh starts discussing the research conducted by Alexander Jacob, retired Director General of Police (DGP Prison, Kerala). Jacob has offered eight theories regarding the root of cyclical violence in the region. According to him, the first miscegenation was primarily due to the Kolarians who lived along the coast of Maharashtra and Gujarat. Their last king was Kartavira Arjuna; he was killed in a fight with Parashurama. His last queen Mahismati was pregnant during his death; she gave birth to Ramakanda Mushkin. The capital of his Kingdom was called Ramanthali (in Payyannur). Srikandapuram, another city in Kannur, was founded by King Srikanta and Vallabhapatanam by King Vallabha. One hundred eighteen kings ruled the Mushika kingdom which was later passed on to the hands of the Cheras who at that time were led by Narmudi Cheral. That was the first infusion of ferocious blood among the people of the region. When Mushikas were defeated, they started training their children in Kalaripayattu(Martial Art) with the sole purpose of fighting battles. However, being from the marginalised community, they could only fight smaller duels over disputes between princelings or local chieftains. Each duel starts with cockfighting in which one cock would get killed. The majority of people who die in the political violence of today are the descendants of Chekavars, the Thiyyas.

The Thorny Road Ahead is the concluding chapter. Under the moderation of Sri. Madanapalle, a peacekeeping meeting was held on 13 July 2016. Pinarayi Vijayan, Kodiyeri Balakrishnan, Kummanam Rajasekharan, 0. Rajagopal, V. Sivan Kutty and Gopalankutty Master were present in the meeting and agreed to maintain a peaceful political climate within the district. Towards the end of the book, Ullekh refers to Alexander Jacob's solutions to end the violence. According to Jacob, Kannur regiment has to be created to tap the aggression of youths in the region for promoting national-building purposes, similar to how the Indian Army accelerated recruitment into the Naga Regiment to tackle the insurgency in Nagaland.

The segregation Marx as the capitalist and the Proletariat is quite replicable as the higher cast and the untouchables in Kerala, where the feudal landlords inherited the wealth and acquired the big cherry of production, which in 
one way created a sense of alienation, where untouchables were not allowed to enter temples or even listen to the Vedic chants., where the scheduled outcast had their own ways of worship and rituals, which prescribed their own code of conduct. Karl Marx, the father of Communist Philosophy strongly resisted against the unseen power and asserted that man has to be led by reason and all that is real is the visible material world and mankind has to strive to fulfil his material needs rather than running behind the unseen entity. The CPI (M) has shown a marvellous example out throwing the feudalist norms and uplifting the untouchables to the equal position of the elite group, which established a space for the Communist in the heart of people and still remains to be the core reason of the thriving party in the state. In a period, where Marxism and its roots are decaying globally, the state of Kerala remains as the abode of the thriving Communist Party, where the traces of history showcases the first elected Communist government in the world. The Communist Party of India (Marxist) (abridged CPI (M)) rose up out of a split from the Communist Party of India in 1964. It is only in Kerala where the roots of the Communist party went deep into the hearts of people and the reforms are still cherished in uplifting the outcast. CPI(M)-led Left Democratic Front (LDF) came to power in 1987,1996,2006 and 2016. However, in the Loksabha elections held in 2019, the party won only one seat because it cannot cope up with the national trends. It is also a matter of fact that political murders increased significantly in the years when $\mathrm{CPI}(\mathrm{M})$ and its allies were in power and went down during the Congress rule. Ullekh's book makes a social analysis of the retributive violence of $\mathrm{CPI}(\mathrm{M})$ and RSS cadres. Kannur Inside India's Revenge Politics is an important book of genuine interest to anyone who is interested in the study of Kerala politics, modern Kerala history and political vendettas. In short, the text is highly readable and futuristic as it highlights the grey shades of violent Kerala political scenario and deeper nuances of Marxism.

\section{References}

Express, F. (2020). At 4,500, Kerala has highest number of shakhas held daily in the country:

Senior RSS leader.

https://www.financialexpress.com/indianews/at-4500-kerala-has-highest-number-ofshakhas-held-daily-in-the-country-senior-rssleader/1892969/

Kallungal, D. (2019, 25 October). NDA vote share improves from $11.7 \%$ to $28.68 \%$. The New Indian Express.

https://www.newindianexpress.com/states/ker ala/2019/oct/25/nda-vote-share-improvesfrom-117-to-2868-2052717.html

Sasidharan, T. (2012). Idathupakshavum Kannur Rastreeyavum (Radical Politics of Kannur). Mathrubhumi Printing. 